\title{
Tracking the movements of translocated elephants in Malaysia using satellite telemetry
}

\author{
Michael Stüwe, Jasmi B. Abdul, Burhanuddin Mohd. Nor and \\ Christen M. Wemmer
}

\begin{abstract}
Malaysia incurs damage worth millions of dollars annually from elephants feeding in plantations. In response, the Malaysian Wildlife Department has translocated over 392 elephants from plantations into protected areas since 1974. Dense rain forest and steep terrain at the release sites have made it near impossible to follow the movements of the released elephants and evaluate the success of the programme. In October 1995, a translocated female elephant was fitted with a satellite transmitter to determine its post-release movements. By August 1996, the female had moved within a range of $7000 \mathrm{sq} \mathrm{km}$. The movements were erratic initially and covered a large area. They were followed by a shift in location twice, each time covering successively smaller areas. Attempts to locate and follow the female on the ground revealed no evidence that she travelled in a group. A second, male, elephant was equipped with a satellite transmitter in February 1996 and by August 1996, it had moved within a range of $350 \mathrm{sq} \mathrm{km}$. An attempt to locate and follow the male on the ground provided evidence that he was in a group of at least three individuals. The difference in the behaviour of the two elephants, released at exactly the same location, is striking, but additional elephants need to be followed to increase sample size and allow a scientific explanation of the findings.
\end{abstract}

\section{Introduction}

Over 30 per cent of Peninsular Malaysia's landmass is covered by rubber or oil palm plantations (Department of Wildlife and National Parks (DWNP)/Danish Co-operation for Environment and Development, unpubl. data), the result of two major phases of land development, starting in the 1910s and 1960s, respectively. Each phase led to a dramatic increase in human-elephant conflicts. There was not only less forest for the resident elephants to feed in, but some plantation trees and crops seemed to be so attractive to elephants that they seemed to prefer them to forest plants. The most common resolution of the conflict was to kill the offending elephants (Ratnam, 1984). Between 1967 and 1977 alone, 120 cropraiding elephants were killed (Kahn, 1991). In

68
1974 the DWNP developed an alternative strategy: translocations. From 1974 to 1995 , DWNP caught 392 offending elephants in fields and plantations, and released them in three protected areas (Abdul et al., 1996).

The method of translocation has been much refined over the past 20 years (Daim, 1995). When serious complaints about elephants are received, DWNP officials evaluate the damage to the plantation and the methods in place to prevent elephants from destroying crops. If they decide the incident is severe enough to remove the offending elephant(s), trackers pick up the signs of the elephant(s) at the point where the most recent damage occurred. They tranquilize the elephant, chain it to a tree, and cut a path through the forest from the capture point to the closest road. The captured elephant is chained to two work (C) $1998 \mathrm{FFI}$, Oryx, $32(1), 68-74$ 
elephants from DWNP's elephant training centre and led on to a truck, which transports it during the relatively cool hours of the night to one of three release areas on the Malaysian Peninsula: Endau Rompin, Ulu Belum or Taman Negara. So far, most elephants have been released inside the large continuous forest tract of the 4343-sq-km Taman Negara National Park $\left(4^{\circ} 82^{\prime} \mathrm{N}, 104^{\circ} 74^{\prime} \mathrm{E}\right)$.

Little information on the fate of the translocated elephants is available. Kahn (1992) believed that elephants successfully established themselves because no carcasses were found at the release sites. A DWNP VHF-based ground telemetry study to determine the movement patterns of translocated elephants delivered discouraging results (DWNP, pers. comm.). Few locations were obtained because the signals of the released elephants could not be tracked for more than a few days after the release of the animal. The dense rain forest and the steep, hilly terrain prevented reception of the VHF signals over long distances and made pursuit of the elephants difficult.

\section{Objectives}

Human-elephant conflicts in much of Asia are likely to increase as land development accelerates. Elephant management techniques must adapt to address the conflict situations. We designed this project to: (i) determine whether elephants translocated in Peninsular Malaysia successfully establish themselves in their new environment; (ii) identify the strategies that translocated elephants use to explore and settle in their new environment; and (iii) identify the characteristics of the most appropriate sites for future releases of elephants in Peninsular Malaysia. The study is ongoing (Stüwe, 1996). Here we report on the strikingly different post-release movements of the first two elephants studied.

\section{Methods}

In 1994, we decided to use the ARGOS satellite telemetry system to follow the movements of translocated elephants, despite some drawbacks of the technology for this type of study: (i) high equipment and transmission costs, which were likely to limit sample size; (ii) low accuracy of individual locations, which would prevent a detailed habitat analysis; and (iii) unreliable data transmission in forested habitats with dense canopies, which would probably limit sample size.

We argued that: (i) tracking the movements of even a few translocated elephants would provide important information on the usefulness and success of this technique for elephant conservation management; (ii) translocated elephants would probably move long distances, which satellite telemetry could determine with high enough accuracy, and habitat analysis, even when done at the low resolution provided by ARGOS, would still yield enough information to detect general habitat selection strategies determining the movements of the released individuals; and (iii) few and irregular data transmissions were acceptable because we were not primarily interested in time budgets and detailed habitat use patterns.

We used two ARGOS satellite transmitter platforms sponsored by Microwave Telemetry, Inc., which were mounted on Telonics, Inc. VHF elephant transmitter collars. Platforms were set to transmit for 24 continuous hours every 3 days. We were thus able to reduce ARGOS transmission processing fees but still follow elephants during full 24-hour cycles. Field testing had shown that the density of the rain-forest canopy at the release site severely reduced the number of times the transmitter signal reached the satellites. However, elephants regularly visit water sources (McKay, 1973; Thouless, 1996), and we hoped that the canopy there would be more open. We did not know when elephants in the release area were likely to go to water, and whether they did so regularly at the same time, but assumed that one or more drinking periods would occur during each 24-hour cycle.

Satellite transmitters were attached during regularly scheduled translocations of cropraiding elephants. We did not select specific individuals, although we planned to alternate the sex of the individuals used in the study. 

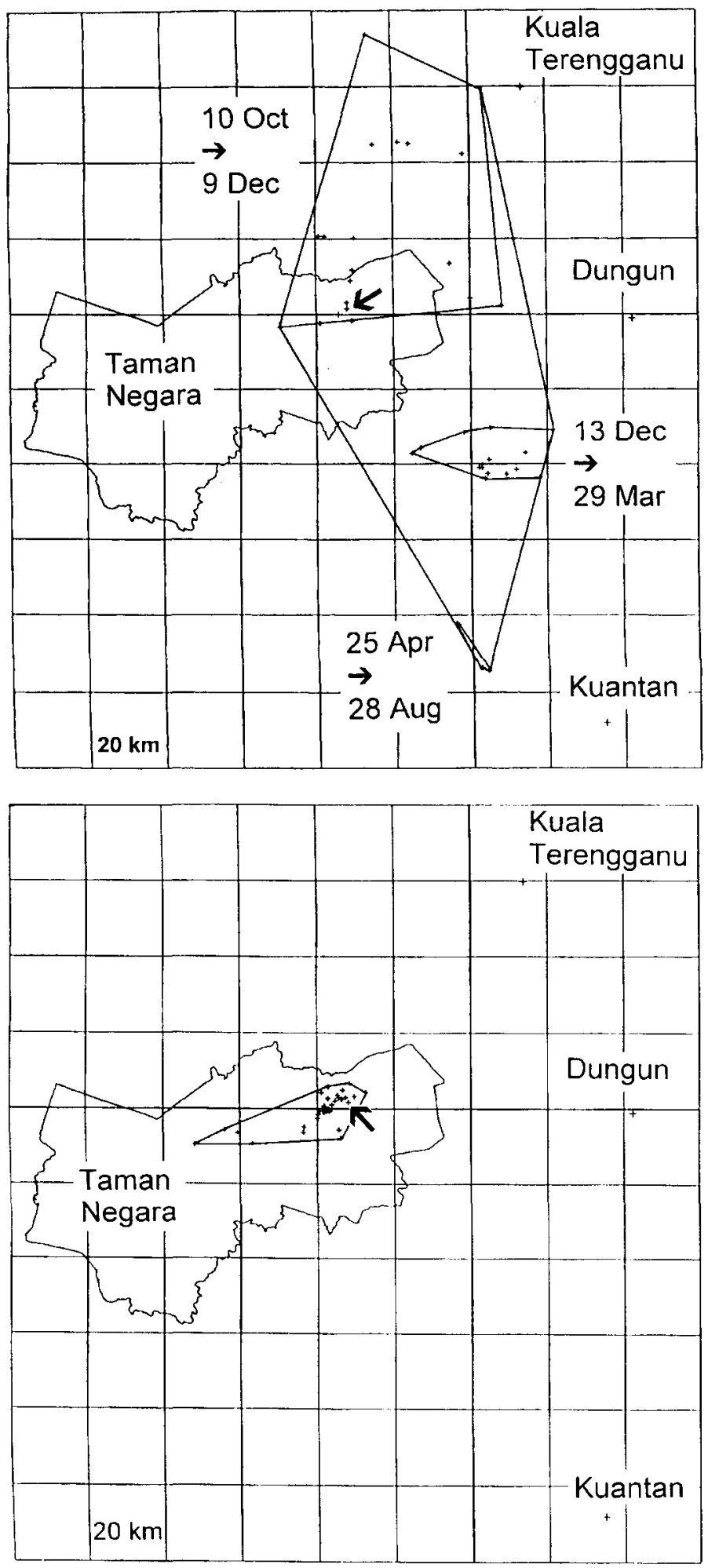

Figure 1. - , 6804-sq-km travel range of female elephant between 10 October 1995 and 28 August 1996 (large polygon). The smaller polygons outline the travel ranges during three consecutive periods within that time period. The elephant was released inside Taman Negara National Park in central Peninsular Malaysia (arrow). Grid cells cover $400 \mathrm{sq}$ $\mathrm{km}$ each.
Figure 2. -, $343 \mathrm{sq} \mathrm{km}$ travel range of male elephant between 8 February and 12 August 1996. It was released at the same spot (arrow) as the female inside Taman Negara National Park in central Peninsular Malaysia. Grid cells cover $400 \mathrm{sq} \mathrm{km}$ each.

(C) $1998 \mathrm{FFI}$, Oryx, 32 (1), 68-74 
The female elephant, with satellite transmitter attached, is loaded on to a barge to cross Lake Kenyir en route to Taman Negara from the capture site (Michael Stüwe).

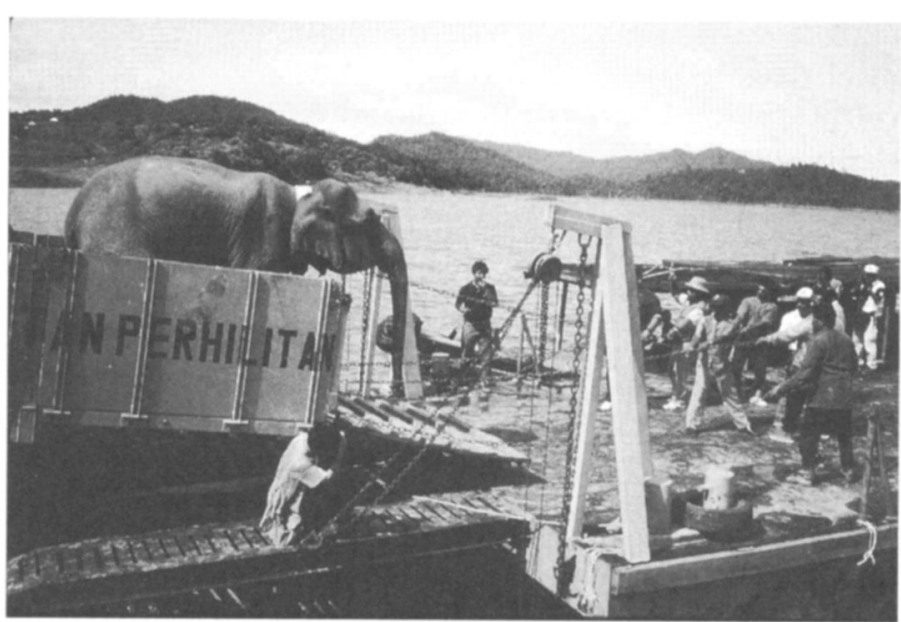

On 10 October 1995, we attached the first transmitter to an approximately 30-year-old female. It was captured south-east of Kota Tinggi in Johore state $\left(1^{\circ} 77^{\prime} \mathrm{N}, 104^{\circ} 209^{\prime} \mathrm{E}\right)$ and was moved c. $400 \mathrm{~km}$ north to Taman Negara National Park. We received the last location on 28 August 1996. On 8 February 1996, we attached the second transmitter to an approximately 25-year-old male, captured south-west of Muadzam Shah in Pahang state $\left(3^{\circ} 074^{\prime} \mathrm{N}\right.$, $103^{\circ} 075^{\prime} \mathrm{E}$. It was released at the same site as the female, c. $200 \mathrm{~km}$ north of the capture point. We received the last location on 12 August 1996. We do not know why the second transmitter worked for only 6 of the estimated 9 months.

In addition to the satellite locations, we located the female by helicopter on 1 day in May 1996 and 3 days in June 1996. During these and three other search periods covering a total of 73 days, we were unable to locate the female from the ground but finally did so on 19 October 1996. We successfully located the male elephant on the ground during a search period of 14 days in April 96. In our analysis we used only one location from each of the three successful search periods so that these periods were not over-represented in the data set. We subjectively eliminated one satellite location for each animal because they were obvious errors.

We used the minimum convex polygon module of the software package MCPAAL $v 1.5$
(Stüwe et al., 1997) to calculate home ranges of the two elephants. Here, we will use the term travel range instead of home range to indicate that we do not consider the area covered by the translocated elephants to be home ranges in the traditional sense, but rather areas traversed after translocation.

\section{Results}

The female elephant's transmitter signal reached satellites on 139 out of 2907 passes ( 4.8 per cent) over a period of 323 days (the number of passes include those during which the transmitter was turned off). Longitude/ latitude locations could be calculated from 37 of the 139 passes (26.6 per cent). The male's signal reached satellites during 106 of 1674 passes (6.3 per cent) over 186 days. Longitude/ latitude locations could be calculated from 42 of the 106 passes (39.6 per cent). Most of the locations were in ARGOS categories B and A, which have the lowest accuracy rating.

The female elephant moved within a range of $6804 \mathrm{sq} \mathrm{km}$ during the 323-day period during which we received its signal (Table 1 ). We distinguished three time periods during which the female travelled inside ranges whose centres were $c .60$ and $50 \mathrm{~km}$ apart, respectively (Figure 1). The time periods were distinctly different in that each lasted longer, covered a smaller range, and had fewer 
locations than the previous one. The female's travel range between release on 10 October and 9 December 1995 was 2969 sq km (61 days, $n=21$ ), between 13 December 1995 and 29 March 1996 it was $349 \mathrm{sq} \mathrm{km} \mathrm{(108} \mathrm{days,} n=15$ ), and between 25 April and 28 August 1996 it was $9 \mathrm{sq} \mathrm{km}$ (126 days, $n=5$ ). Within 2 weeks of its release the female had left the continuous forest tract of Taman Negara and moved to an area with oil palm plantations, subsequently continuing to move on the boundary of plantation and forest land. During our intensive 3-week search for the female in the third and smallest intensively used area, we did not find evidence of any other elephants.

The male moved within a range of $343 \mathrm{sq}$ $\mathrm{km}$ during the 186-day period we received signals (Table 1). We did not detect shifts in the travel range for specific time periods. The male continued to move in the general area of its release site, only travelling, on two occasions, to an area about $30 \mathrm{~km}$ east of the centre of its range (Figure 2). This elephant never left the continuous forest of Taman Negara and tracks showed that for at least 2 days in May 1996, it travelled with two other elephants.

Table 1. Home range sizes of Asian and African elephants (calculated as minimum convex polygon)

\begin{tabular}{|c|c|c|c|c|c|c|c|}
\hline Country & Habitat & $\begin{array}{l}\text { Home } \\
\text { range } \\
(\mathrm{sq} \mathrm{km} \text { ) }\end{array}$ & $\begin{array}{l}\text { Tracking } \\
\text { technique }\end{array}$ & $\begin{array}{l}\text { No. days } \\
\text { tracked }\end{array}$ & No. obs. & No./sex & Study \\
\hline Malaysia & $\begin{array}{l}\text { Rain forest, } \\
\text { plantations }\end{array}$ & 6804 & Satellite & $\begin{array}{l}323 \\
\text { telemetry }\end{array}$ & 41 & 1 female & $\begin{array}{l}\text { This } \\
\text { study }\end{array}$ \\
\hline Malaysia & Rain forest & $59-167$ & $\begin{array}{l}\text { Aerial } \\
\text { telemetry }\end{array}$ & $?$ & $<15$ & 2 females & $\begin{array}{l}\text { Olivier, } 1978 \text { (in } \\
\text { Baskaran et al., } \\
\text { 1995) }\end{array}$ \\
\hline India & $\begin{array}{l}\text { Dry and } \\
\text { moist } \\
\text { deciduous } \\
\text { forest }\end{array}$ & $530-800$ & $\begin{array}{l}\text { Ground } \\
\text { telemetry }\end{array}$ & $630-720$ & $106-341$ & 3 females & $\begin{array}{l}\text { Baskaran et al., } \\
1995\end{array}$ \\
\hline India & $\begin{array}{l}\text { Dry } \\
\text { deciduous } \\
\text { forest }\end{array}$ & 34 & $\begin{array}{l}\text { Ground } \\
\text { telemetry }\end{array}$ & $>365$ & 277 & 1 female & $\begin{array}{l}\text { Joshua and } \\
\text { Johnsingh, } 1995\end{array}$ \\
\hline India & $\begin{array}{l}\text { Dry and } \\
\text { moist } \\
\text { deciduous } \\
\text { forest }\end{array}$ & $105-115$ & Sightings & $696-705$ & $14-15$ & 2 females & Sukumar, 1989 \\
\hline Malaysia & $\begin{array}{l}\text { Rain forest, } \\
\text { plantations }\end{array}$ & 343 & $\begin{array}{l}\text { Satellite } \\
\text { telemetry }\end{array}$ & 186 & 43 & 1 male & This study \\
\hline India & $\begin{array}{l}\text { Dry and } \\
\text { moist } \\
\text { deciduous } \\
\text { forest }\end{array}$ & $211-375$ & $\begin{array}{l}\text { Ground } \\
\text { telemetry }\end{array}$ & $450-540$ & $113-224$ & 2 males & $\begin{array}{l}\text { Baskaran et al., } \\
1995\end{array}$ \\
\hline India & $\begin{array}{l}\text { Dry } \\
\text { deciduous } \\
\text { forest }\end{array}$ & 200 & $\begin{array}{l}\text { Ground } \\
\text { telemetry }\end{array}$ & $>365$ & 469 & 1 male & $\begin{array}{l}\text { Joshua and } \\
\text { Johnsingh, } 1995\end{array}$ \\
\hline India & $\begin{array}{l}\text { Dry and } \\
\text { moist } \\
\text { deciduous } \\
\text { forest }\end{array}$ & $170-320$ & Sightings & $280-780$ & $7-12$ & 3 males & Sukumar, 1989 \\
\hline Namibia & $\begin{array}{l}\text { Arid } \\
\text { savannah }\end{array}$ & $2136-10738$ & $\begin{array}{l}\text { Satellite } \\
\text { telemetry }\end{array}$ & $137-207$ & $35-67$ & 7 males & $\begin{array}{l}\text { Lindeque and } \\
\text { Lindeque, } 1991\end{array}$ \\
\hline Kenya & $\begin{array}{l}\text { Montane } \\
\text { forest, arid } \\
\text { bushland }\end{array}$ & $102-5527$ & $\begin{array}{l}\text { Aerial } \\
\text { telemetry }\end{array}$ & $365-750$ & $16-88$ & 17 males & Thouless, 1996 \\
\hline
\end{tabular}




\section{Discussion}

The $6804-\mathrm{sq}-\mathrm{km}$ travel range of the female elephant was very large compared with home ranges of Asian elephants reported elsewhere (34-800 sq km, Table 1), although it was comparable with home ranges of some African elephants Loxodonta africana, which migrated between distant resources (Table 1). When our female's last two intensively used ranges are viewed independently ( 349 and $9 \mathrm{sq} \mathrm{km}$ ) they were well within the general size reported for female Asian elephants (Table 1). In contrast to the female, the male's travel range of $343 \mathrm{sq}$ $\mathrm{km}$ was similar to home ranges of other male Asian elephants, which were reported to range from 170 to $375 \mathrm{sq} \mathrm{km}$ (Table 1).

Many of our satellite locations had very low accuracy ratings, probably because the dense rain-forest canopy prevented enough signals reaching the satellites during any given pass. But our low-accuracy locations were clustered with the few high-accuracy locations. On the two occasions we tried, we were immediately able to locate the elephants from the air using the latest available satellite locations. We excluded two obviously wrong and far outlying locations from the analysis. Because of the above, we believe our calculations are based on reasonably accurate data. The overall size of the travel ranges reduced the relative importance of low-resolution individual locations. We used the minimum convex polygon algorithm to calculate our home range sizes. Many authors provide data in this format, so they can easily be compared across projects. Although minimum convex polygon home ranges may not necessarily be an accurate reflection of an animal's spatial use (Baskaran et al., 1995), the difference between our female's travel range and the home ranges of other studied female Asian elephants was so big that no methodological inconsistencies could account for it. We suggest that it might be an effect of the translocation process. Because our small sample size does not allow a scientific interpretation of the data, we will here view our data as part of a case study and interpret them accordingly.

The male established its travel range around its release site, never left the forest and, during the 6 months we were able to track it, had a travel range equivalent to annual home ranges of resident Asian elephants in India (Table 1). The male seemed to have established a new home range soon after its release, at the site of its release, and in an area with other elephants. It also appeared to associate with other resident elephants.

The female's total travel range was almost $7000 \mathrm{sq} \mathrm{km}$ over 8 months. During the first 2 months, this animal moved far and seemingly erratically in a range of almost $3000 \mathrm{sq} \mathrm{km}$. After a major shift, it then travelled in a much smaller area $(350 \mathrm{sq} \mathrm{km})$ for 3 months. After yet another shift, it settled in an even smaller range of only $9 \mathrm{sq} \mathrm{km}$ for the following 5 months. Most of the time, the female seemed to travel in the border area between forest and plantation land, and there was no evidence that it travelled with other elephants.

Adult African elephant males form associations of often changing composition with other males, or travel alone. African elephant females remain in closely knit multi-generation family groups (Hendrichs and Hendrichs, 1971; Douglas-Hamilton and DouglasHamilton, 1975). Assuming similar social structures for Malaysia's Asian elephants, we surmise that our male may have had fewer problems adjusting to the strange environment and may have had an easier time joining or being joined by other males. Our female was taken out of her family group during capture. It might have searched for its family group since its release.

If the above assumptions should prove to be a general trend, current translocation practices for females may need to be reviewed. While translocations of single males may not prevent them from establishing normal home ranges at or near the release site, females may need to be translocated with other members of their family group to establish a core group at the new site. Interactions between group members might facilitate the adjustment of the group to its new environment. The core group might begin to reproduce and grow into a full family group faster than would single translocated females. 
The surprising results clearly indicate a strong need for more data to evaluate the success of elephant translocations in this inaccessible rain-forest habitat. The study will continue and additional elephants will be fitted with satellite transmitters as funds become available to pay for the expensive technology.

\section{Acknowledgements}

We would like to thank Mr Nasaruddin and his elephant management unit for their dedicated work during the elephant captures and the ground-tracking. Z.Z. Abidin, S. Dawson, and S. Worah kindly reviewed earlier drafts of this manuscript. Financial and/or technical assistance to the project was provided by Smithsonian Institution Women's Committee, Friends of the National Zoo, Microwave Telemetry, Inc., Outdoor Life Network, CBS News, Reuters, THB Asia Connect, Smith Kline Beecham and British Airways. Without all these contributions this project would not have been possible.

\section{References}

Abdul, J.B., Daim, M.S.B., Othman, N.B. and Ibrahim, M.A.B. 1996. Elephant Management in Peninsular Malaysia. Unpublished manuscript, Department of Wildlife and National Parks, Kuala Lumpur, Malaysia.

Baskaran, N., Balasubramanian, M., Swaminathan, S. and Desai, A.A. 1995. Home range of elephants in the Nilgiri Biosphere Reserve, South India. In $A$ Week with Elephants (eds. J. C. Daniel and H. S. Datye), pp. 296-313. Bombay Natural History Society, Bombay.

Daim, M.S. 1995. Elephant translocations: the Malaysian approach. In $A$ Week with Elephants (eds. J. C. Daniel and H. S. Datye), pp. 242-248. Bombay Natural History Society, Bombay.

Douglas-Hamilton, I. and Douglas-Hamilton, $\mathrm{O}$. 1975. Among the Elephants. Viking Press, New York.

Hendrichs, H. and Hendrichs, U. 1971. Dikdik und Elefanten. R. Piper Verlag, München.

Joshua, J. and Johnsingh, A.J.T. 1995. Ranging patterns of elephants in Rajaji National Park: implications for reserve design. In $A$ Week with Elephants (eds. J. C. Daniel and H. S. Datye), pp. 256-260. Bombay Natural History Society, Bombay.

Kahn, M. 1991. The Malayan elephant - a species plan for its conservation. Department of Wildlife and National Park Peninsular Malaysia, Kuala Lumpur, Malaysia.

Kahn, M. 1992. Is translocation a management tool? Gajah, 9, 15-18.

Lindeque, M. and Lindeque, P. M. 1991. Satellite tracking of elephants in northwestern Namibia. African Journal of Ecology, 29, 196-206.

McKay, G.M. 1973. Behavior and ecology of the Asiatic elephant in Southeastern Ceylon. Smithsonian Contributions to Zoology, 125, 1-113.

Olivier, R.D.C. 1978. On the ecology of the Asian elephant. $\mathrm{PhD}$ thesis, University of Cambridge, Cambridge, UK.

Ratnam, L. 1984. An exercise in elephant management. Biotrop Special Publication, 21, 129-139.

Stüwe, M. 1996. The Malaysian elephant satellite tracking project. Http://www.si.edu/elephant.

Stüwe, M., Blohowiak, C. and Byrne, E. 1997. Microcomputer Programs for the Analysis of Animal Locations. Conservation \& Research Center, Smithsonian Institution, Front Royal, VA, USA.

Sukumar, R. 1989. The Asian Elephant-Ecology and Management. Cambridge University Press, Cambridge, UK.

Thouless, C.R. 1996. Home ranges and social organization of female elephants in northern Kenya. African Journal of Ecology, 34, 284-297.

Michael Stüwe, Conservation \& Research Center, Smithsonian Institution, Front Royal, VA 22630, USA. E-mail: mstuewe@sover.net

Christen M. Wemmer, Conservation \& Research Center, Smithsonian Institution, Front Royal, VA 22630, USA. E-mail: nzpem002@sivm.si.edu

Jasmi Abdul, Department of Wildlife and National Parks, Km 10, Jalan Cheras, 50664 Kuala Lumpur, Malaysia. E-mail: kp@jphltn.sains.my

Burhanuddin Mohd. Nor, Department of Wildlife and National Parks, Km 10, Jalan Cheras, 50664 Kuala Lumpur, Malaysia. E-mail: kp@jphltn.sains.my

Received 3 March 1997

Accepted 18 August 1997 